\title{
SPECIES COMPOSITION AND POPULATION DYNAMICS OF THE PHYTOPLANKTON COMMUNITY IN KOTMALE RESERVOIR
}

\author{
NISHANTHI PEIRERA ${ }^{1}$ and SWAIRNA PIYASIRI ${ }^{2}$ \\ ' Department of Zoology, The Open University, Nawala, Nugegoda. \\ ${ }^{2}$ Department of Zoology, University of Sri Jayewardenapura, Nugegoda.
}

(Received: 17 October 1996 ; accepted: 08 January 1999)

\begin{abstract}
The present work was carried out in the Kotmale reservoir from April 1994 to April 1996 with the objective of studying the species composition and the seasoral, spatial and diurnal distribution of phytoplankton. The phytoplankton of the reservoir was composed of four major families: Chlorophyceae, Cyanophyceae, Bacillariophyceae and Dinophyceae. Chlorophyceae dominated the phytoplankton, with Staurastrum. species forming the major component. The results show seasonal variation in the major phytoplankton types of the reservoir that correlates with the water level. During the wet months, Staurastrum species dominated the phytoplankton while in the dry months Microsystis aeruginosa became prominent especially in the upstream region of the reservoir. This periodic occurrence of $M$. aeruginosa bloom was a prominent feature of the impoundment. Although the filamentous diatom, Melosira species and the dinoflagellate, Peridinium cinctum formed an important part of the plankton community, no contrasting periodicity was observed as in $M$. aeruginosa.

A clear vertical and diurnal migration pattern was observed among the major phytoplankton types. Microcystis showed a downward movement during noon, while $P$. cinctum was very abundant in the surface during early morning. The phytoplankton forms a major part of the food consumed by the fish in the Kotmale reservoir and the knowledge gained through this investigation will help to improve the commercial fishery of the impoundment.
\end{abstract}

Key words: Kotmale reservoir, Microcystis, phytoplankton periodicity, Staurastrum species.

\section{INTRODUCTION}

The Kotmale reservoir is the uppermost impoundment in Sri Lanka and was constructed in 1985, under the Accelerated Mahaweli programme for the generation of hydroelectricity. A $87 \mathrm{~m}$ high rock filled dam was built across the Kotmale Oya, which is a main tributary of the river Mahaweli, to create the 174 million cubic meter capacity reservoir. ${ }^{1}$ According to the information gathered since 1987, Kotmale is a thermally stratified waterbody indicating a clinograde type of dissolved oxygen curve $e^{2,3}$ and the reservoir is very sensitive to eutrophication. ${ }^{3}$ The intensity of eutrophication was indicated by the thick

Corresponding author 
bloom of Microcystis aeruginosa in 1991, that occurred despite high flow through rates.

The extensive enrichment of the reservoir is mainly due to the delivery of nutrients through agricultural and urban sources of the catchment. ${ }^{4,5,6}$

A study was commenced in April 1994, with the objective of investigating types of fish plankton interactions in the reservoir and the possibility of using fish for controlling the bloom during extreme situations. The present paper deals with the observations on species composition, seasonality and diurnal migration patterns of the phytoplankton community of the waterbody, related to the above study.

\section{METHODS AND MATERIALS}

Fig. 1 illustrates the sampling locations.

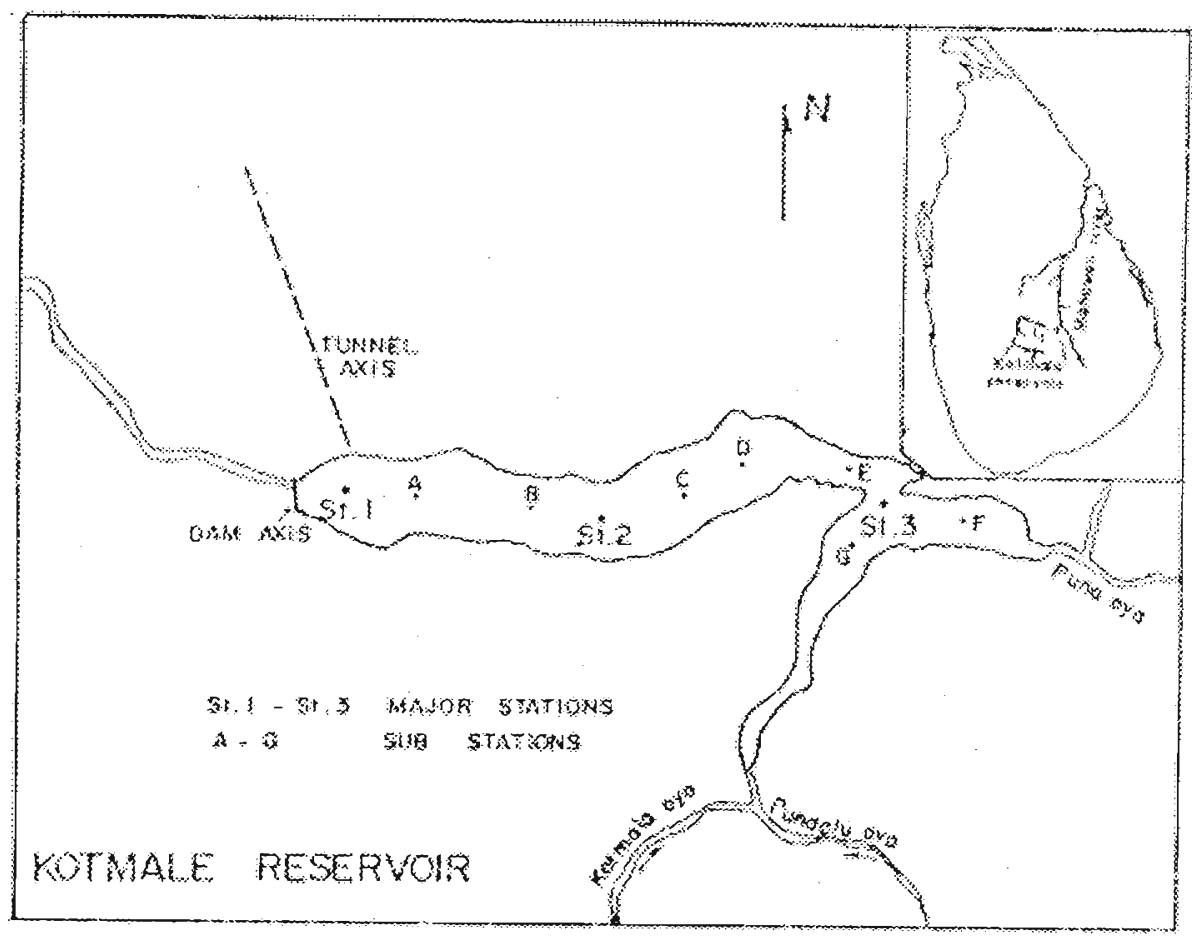

Figure 1: Locaion of the Kotmale reservoir and sampling stations. 
Phytoplankton samples were collected once a month using a closing type net (mesh size, $30 \mu \mathrm{m}$ ) which was attached to a winch and operated by a boat. Samples at $10 \mathrm{~m}$ intervals were taken from bottom to surface at the Major station 1, during the period of study. Horizontal samples were collected from three major stations ( $\mathrm{M} 1, \mathrm{M} 2$ and $\mathrm{M} 3$ ) and two sub stations ( $\mathrm{F}$ and $\mathrm{G}$ ) by dragging. the net for one minute while the boat was moving at a very slow speed. These plankton samples were collected between 1000 and 1300h. Three diurnal samplings were carried out at six hourly intervals to find out the diurnal migration patterns of the plankton. These samples were immediately transferred into pre-labelled bottles and preserved in 5\% formalin. In the laboratory, the samples were diluted to a known volume and shaken thoroughly to achieve a uniform distribution before $1 \mathrm{ml}$ was pipetted out on to a Sedgwick-Rafter cell. The phytoplankton were identified with the aid of Abeywickrama, ${ }^{\top}$ Abeywickrama \& Abeywickrama ${ }^{8}$ and Whitford \& Schumacher, ${ }^{9}$ using a light microscope and the mean of the three replicates was taken as the final value. The total numbers of individual species collected at each station and at each depth were quantified and the phytoplankton density was expressed as number of cells per $\mathrm{m}^{3}$ of the reservoir water.

Temperature, pH and conductivity of the surface water samples at each station were measured using a digital thermometer, pH meter (Jenway, model 3070) and a conductivity meter (Jenway, model 4070) respectively. Secchi depth (SD) transparency was determined as the averaged reading derived from lowering and raising a standard $25 \mathrm{~cm}$ diameter, black and white disk (Secchi disk) from the shady side of the boat. From these readings, the euphotic limit $\left(\mathrm{Z}_{\mathrm{cut}}\right)$ of the reservoir was calculated by multiplying with a factor of $2.5 .^{10}$

The data were analysed using Microsoft Excel 5.1 (1985-1992) version and correlation coefficient values $(r$ ) were calculated to find out the significance of the results.

\section{RESULTS}

\section{Species composition and abundance}

Forty three species of phytoplankton were identified during the two year study period and were categorised into four taxonomic groups as indicated in Table 1 , where the major phytoplankton types were grouped according to their abundance. Of these, Chlorophyceae was the most abundant with 26 species while the group Dinophyceae contained only one species, Peridinium cinctum. Cyanophyceae was the second abundant group with 10 species while six species were recorded from the group Bacillariophyceae. Of the Chlorophyceae, the genus Staurastrum was the most dominant, with more than seven species. As indicated in Fig. 2 and 3, during most months, Staurastrum species represented 
over 80 percent of the total phytoplankton population of the reservoir and could be considered as the only genus belonging to the category of 'very abundant'.

Table 1: The species composition and categorisation of the phytoplankton according to their abundance.

Category

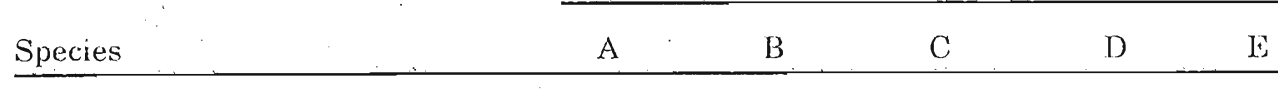

CYANOPHYCEAE

Microcystis aeruginosa

Microcystis incerta

Anabaena species

Ocillotoria species

Lyngbya species

Merismopedia species

Nostoc species

Spirulina species

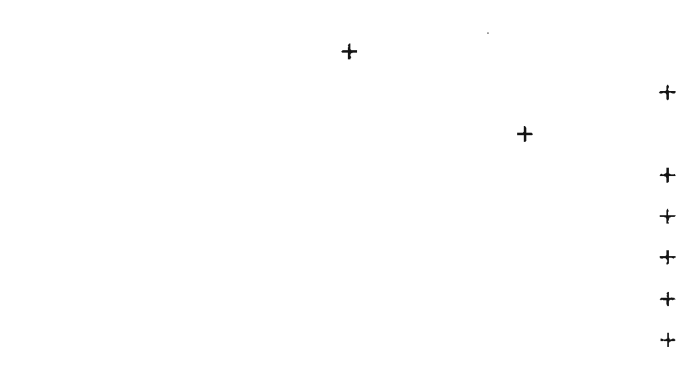

\section{CHLOROPHYCEAE}

Staurastrum species

Cosmariuñ species

Closteriulm speices

Botryococcus species

Eudorina species

Volvox species

Pediastrum species

Scenadesmus species

Andistrodesmus species

Filamentous algae

Xanthidium species

\section{i}




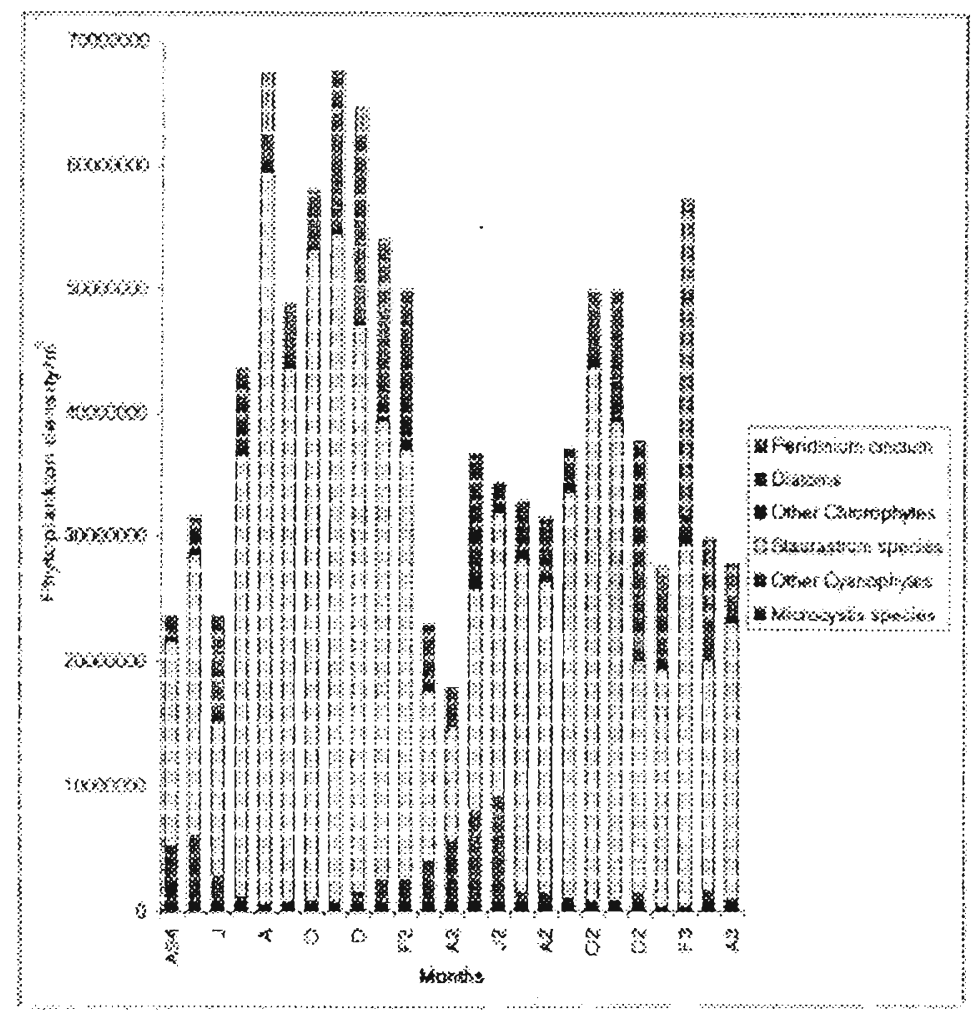

Figure 2: Monthly variation of phytoplankton in 10-0m samples at the Major station 1.

Other than Staurastrum species, Cosmarium species was the only other chlorophyte, which was present throughout the year in considerable amounts.

When considering the Cyanophyceae, Microcystis aeruginosa (over 90 percent) was the most abundant species whereas Microcystis inserta was present in very low numbers. Anabaena species was the only other cyanobacteria present in considerable amounts, but only during certain months.

From the group Bacillariophyceae, the most prominent species was the filamentous form, Melosira species (over 75 percent) while small type of centric diatom was always present in some amounts. Diatoms (Navicula and Frustulia) were rare and their contribution to the total suspended phytoplankton community of the reservoir could be considered as negligible. 


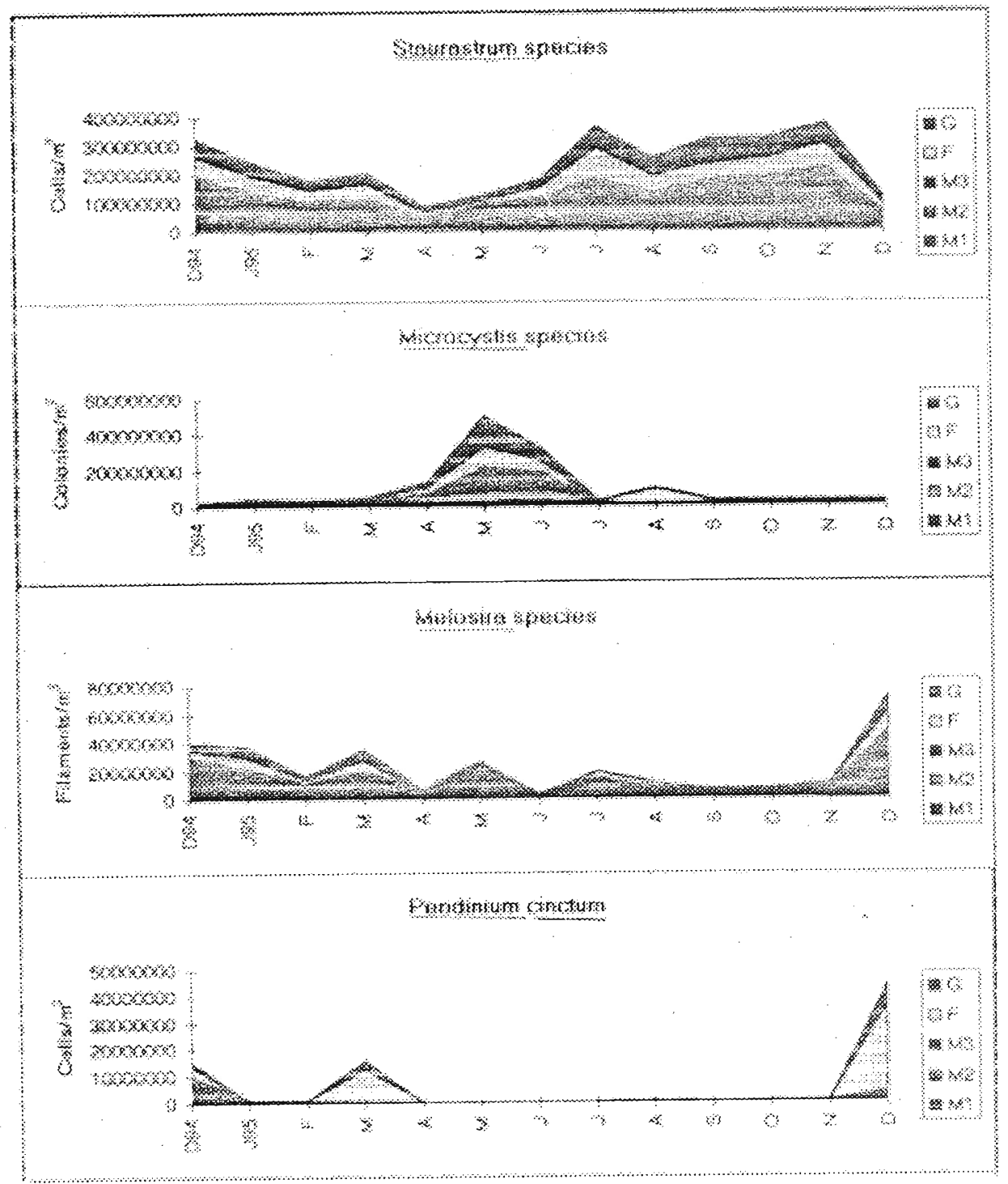

Figure 3: Distribution patterns of 4 major phytoplankton groups in 3 Major stations $(1,2$, and 3 ) and 2 sub stations $(F$ and $G$ ) in the surface layers of the reservoir. 


\section{Seasonal variation of phytoplankton}

Seasonal variations in the population densities of phytoplankton were seen in all stations. As illustrated in Fig. 2, Major station 1 (10-0m depth) showed prominent peaks in various months due to abundance of different phytoplankton types. The peak in August 1994 was due to the dominance of Staurastrum species, while in the period from November to December of the same year, the amount of other chlorophytes, (e.g. Cosmarium species) and diatoms (e.g. Melosira species) were also more abundant together with the Staurastrum.

The largest amount of Melosira species was recorded in December 1995. In February 1996, a large number of $P$. cinctum together with Staurastrum were present in the reservoir. The lowest plankton density was recorded during AprilMay each year and the amount of $M$. aeruginosa was highest cluring this period of the year compared to other phytoplankton types.

According to Fig. 3, the surface samples of the upstream region of the reservoir (Major station 3, sub stations $F$ and $\mathrm{G}$ ) indicated the most prominent phytoplankton peak during May-June 1995 due to the dominance of $M$. aeruginosa.

These figures indicated that Staurastrum species dominated the reservoir phytoplankton population for most part of the year. However, the population density of Staurastrum species dropped when the $M$. aeruginosa dominanted the population. According to Table 2, the negative correlation between the two species was statistically significant. $P$. cinctum and Melosira species were dominant in certain months, but they never showed a contrasting periodic occurrence similar to $M$.aeruginosa.

\section{Spatial distribution of phytoplankton}

All the phytoplankton types were distributed throughout the reservoir water, but some phytoplankton were more common in certain areas of the impoundment (Fig. 3). Particularly, the $M$. aeruginosa and $P$. cinctum showed highest densities in the up stream region. In May 1995, over 85 percent of the phytoplankton population in upstream region, was composed of $M$. aeruginosa while Major station 1 and 2 had 39.3 percent and 52.3 percent respectively. When compared to the above mentioned species, the distribution of Stcurastrum species was more homogeneous while Melosira species was more abundant closer to the dam than in the upstream region. When considering the vertical distribution of the phytoplankton, a considerable amount of individuals were present throughout the water column (Fig.4). 
Table 2: Statistical significance between different parameters.

$\frac{\text { Parameter }}{\text { Staurcustrum and Microcystis }}$

population densities at Major st.3

(surface samples)

12

$-0.590756$

0.05

Maximum water level and total

phytoplankton

$(0-10 \mathrm{~m})$ at Major st. 1)

25

r value

Probability

(surface at Major st.3)

17

$-0.371453$

"Microcystis population

and euphotic depth (Major st.3)

14

$-0.642193$

0.01

"Euphotic zone and surface total

dissolved solids

Major st. 1

Major st. 3

"Secchi depth and surface turbidity Major st. 1

Major st. 3

"Rainfall and maximum water level at Major station 1

\section{Temporal distribtion of phytoplankton}

As illustrated in Fig. 5 the densities of various plankton in different water layers differed with time. The dinotlagellate, $P$. cinctum showed a diurnal migration pattern, showing preference for the surface during early mornings while migrating into deeper waters at other times of the day. Microcystis showed a downward movement during noon and was more abundant in surface layers throughout the day. More homogeneous distribution was shown by Staurastrum species at $1800 \mathrm{~h}$ while Melosira was homogeneously distributed at $2400 \mathrm{~h}$. 


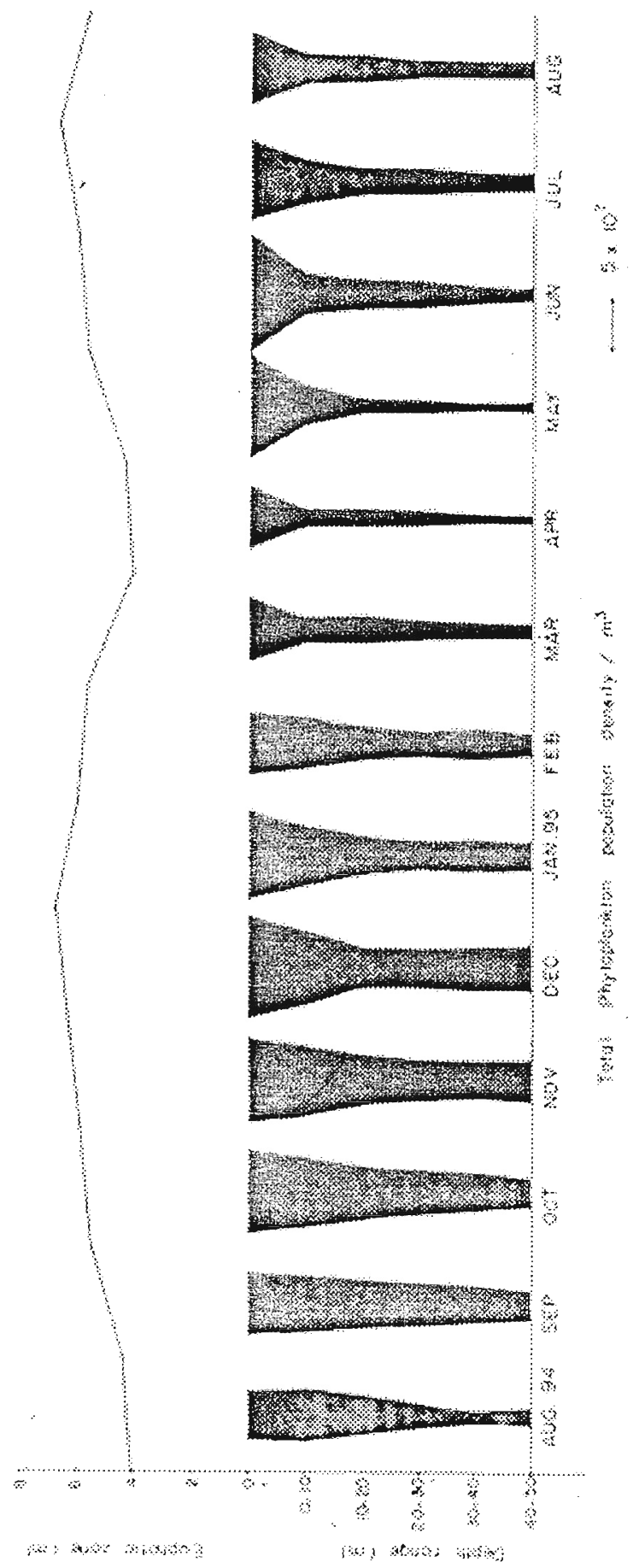

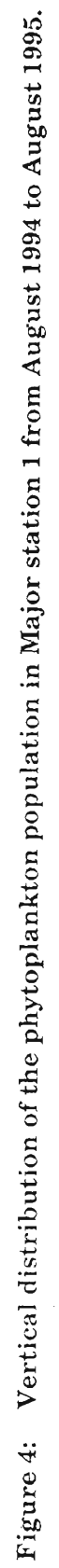




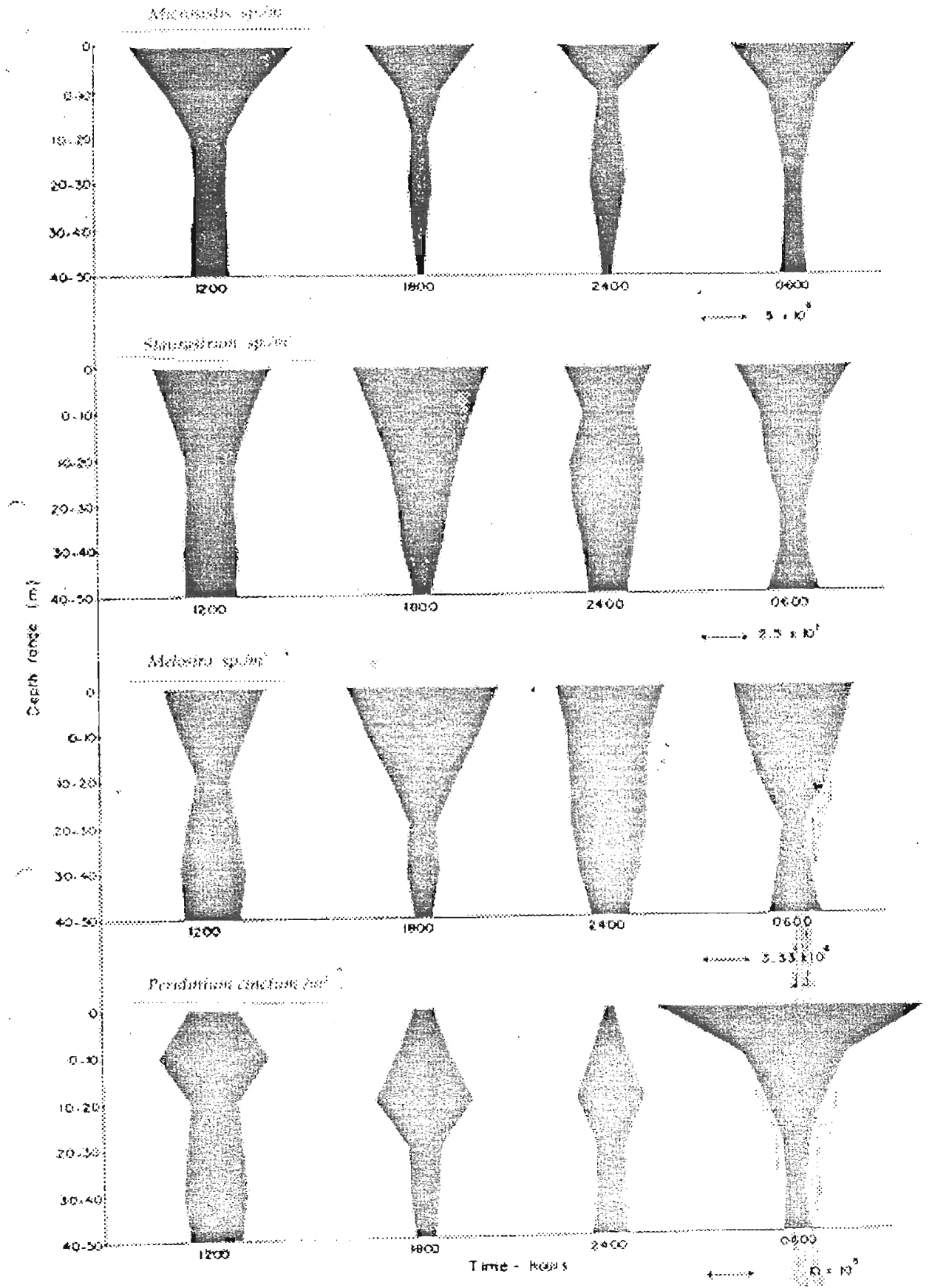

Figure 5: Vertical migration patterns of 04 phytoplankton groups in Major station 1 (December 1995). 


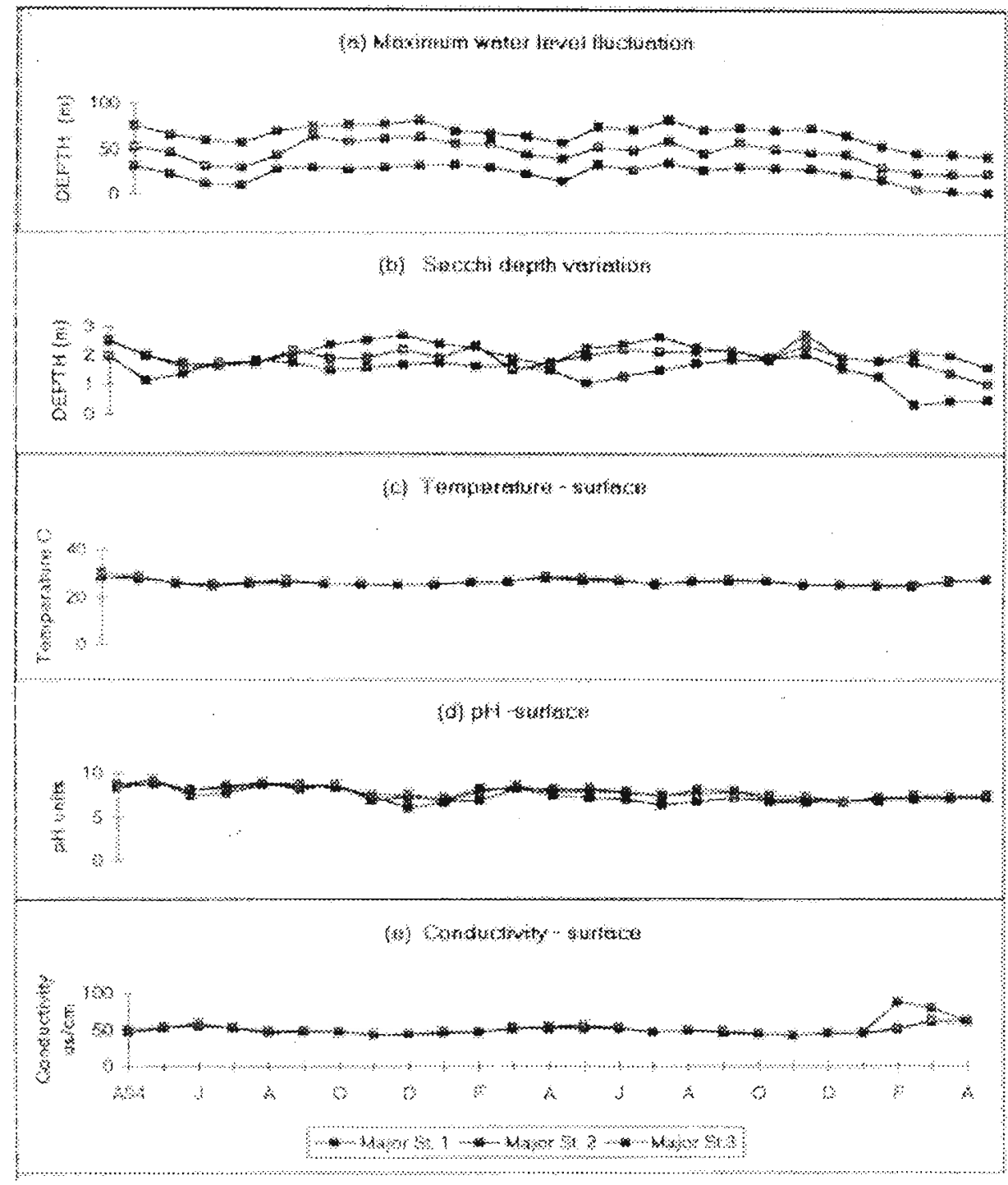

Figure 6: Monthly variation in some environmental parameters of the reservoir water. 


\section{Physicochemical properties and phytoplankton dynamics}

Fig. 6(a) illustrates the water level fluctuation at the three Major stations. Although during the rainy season, the reservoir water level was high, the correlation coefficient value between the two parameters showed a negative value (Table 2). This could be due to the combined effects of lag period between the rainfall of the catchement and water received by the impoundment and due to high flow through rates during power generation.

Secchi depth values varied between 2.7 to $0.33 \mathrm{~m}$ and was higher in Major: station 1 than in other stations. Fig $6($ b) indicates low secchi depth values during low water levels or during drought. This may be correlated either with high phytoplankton growth or with high turbidity of the water due to sediment particles (Table 3). For instance in May 1995, secchi depth value of the Major station 3 was low due to $M$. aeruginosa bloom and in February to April 1996, it was due to large amount of sediment particles.

As shown in Fig. 5 the vertical distribution of total phytoplankton in Major station 1 varied with the euphotic limit. When the euphotic limit was high, the phytoplankton density was also high and the plankton was found throughout the water column. In April to May 1995, the euphotic zone was low and the plankton distribution was limited to the upper water layers.

The temperature variation of the reservoir water was minimum, with temperatures around $26^{\prime \prime} \mathrm{C}$ for most part of the year. The $\mathrm{pH}$ of the water varied between 6.2 to 9.3 (Fig 6). When the Microcystis density was high, the pH and temperature of the reservoir water was also high and the water level was low before the density of Microcystis increased. After the heavy rains in June, the density dropped to low levels in July. Also P. cinctum showed high densities when the water level of the reservoir was low (Fig, 2,3 and 6).

\section{DISCUSSION}

\section{Species composition and abundance}

The present study agrees with the fact, that the phytoplankton communities of the newly built upland reservoirs of the river Mahaweli are dominated by the family Chlorophyceae, and Staurastrum species. However, P. cinctum which significantly contributed to the total phytoplankton of the Kotmale reservoir was not recorded from Victoria and Rantambe. ${ }^{11.12}$

In the lowland reservoirs of Sri Lanka, (e.g. Parakrama Samudra), Chlorophyceae were represented by a large number of species, but in low densities and the dominant phytoplankton group was the cyanophyta. ${ }^{1:}$ It is 
correlated with the fact that they are limnologically different from the upland reservoirs in their morphology and flow through regimes. ${ }^{14}$

Lake George of Uganda, which is a shallow tropical fresh water body was dominated by Microsystis species ${ }^{15}$ while in water bodies in Kenya, the prominent phytoplankton recorded belonged to the family Chlorophyceae. ${ }^{165}$

\section{Seasonal variation}

According to Horne \& Goldman, ${ }^{17}$ phytoplankton is subjected to strong seasonal influences. In the temperate and polar zones, there is a great contrast between the summer and the winter and in the tropics between the rainy and the dry seasons. Algae respond to this contrast rearrangement of the physical and chemical structure of their environment with characteristic population fluctuations.

The seasonal variation of phytoplankton community in the Kotmale reservoir seems to correlate with water level fluctuations, caused by the rainfall and the out flow due to power generation, seepage and evaporation.

The depth from which water is drawn out for power generation depends on the water level as the water entering the tumnel may originate from near the surface or at must from a depth of $35 \mathrm{~m}$ when the reservoir is at full supply level. ${ }^{\text {is }}$ This is important since water drawn from the surface is rich in phytoplankton and poor in nutrients compared to water drawn out from lower levels. is

The South West monsoon from May to Septomber brings the highest rainfall to the catchment and February is the driest month. Inter monsoonal periods give more rainfall than the North East monsoon. ${ }^{17}$ Hence for most part of the year, the reservoir has high water levels and during such periods Staurastrum species remain the dominant group. The driest period of the reservoir catchment was generally from December to March and the water level of the reservoir drops especially in the upstream region. During this period due to reduced power generation, the flow through rates were low and the temperature and pII ranges were high. These conditions favoured the dominance of $M$. aeruginosa. .1.19,20 $^{-20}$

Chandrananda" has recorded the highest Microcystis densities during September to November in 1991, and this was due to the fact that the catchment of the reservoir did not experience the south west monsoon adequately. Due to continuous rain in August, nutrient content of the reservoir increased and the bloom formation took place in the following drought with circulated nutrients. ${ }^{4}$ 
According to Ryding \& Rust, ${ }^{21}$ algae can be accumulated to nuisance levels in a lake or a reservoir, only when the algae growth rate is faster than the renewal or the rate of flushing of the water body. During the present investigation, in 1994 and 1995 normal monsoonal rains were experienced. The bloom conditions were observed only during May to June, due to low rainfall from December to March.

During the Microcystis bloom period, the dominant phytoplankton, Staurastrum species dropped to low levels. The dinoflagellate, P. cintum appears to be the only other phytoplankton which reached near to the population densities of Staurastrum species and as recorded by Chandrananda" it appears to increase at times when the water level is very low.

Tundisi, ${ }^{22}$ states that in reservoirs, part of the phytoplankton population is lost by unidirectional water flux and therefore the estimations of the phytoplankton standing crop is always problematic.

\section{Spatial diurnal variations}

Phytoplankton was not evenly distributed in the Kotmale reservoir. Biomass was usually greater in mid stream to upstream regions but lower at greater depths, which agrees with Rott, $1:$ ' who states that there was a distinct difference between the phytoplankton of Southern, Middle and Norther'n parts of the Parakrama samudra during his study period. The sub stations, F and G appear to have the highest population densities of Microcystis and P. cinctum during certain months. This indicates that the intense growth of these species were at the upstream regions. These stations receive nutrient rich water directly from the tributaries (the Kotmala Oya and the Pundalu Oya). They bring the surface runoff from the dense tea estates of the up-country, where intensive use of agrochemicals including fertilizers, pesticides and fungicides is being practised. ${ }^{4,6}$

\section{Diurnal migration}

The studies carried out in different water bodies in Brazil have shown that the diurnal cycles are as important as the seasonal cycles and they establish patterns of spatial heterogeneity, that will produce density gradients interfering with the sinking rates of phytoplankton and the nutrient distribution of the water column. ${ }^{22}$ According to Westlake et al., ${ }^{23}$ diurnal alternations in phytoplankton are only possible if their migratory velocities exceed the rate of vertical displacement of water by turbulence. Migration by changing buoyancy and active migration by flagellates are the common mechanisms involved. 
In the Kotmale reservoir both types of migrations were observed. Microcystis species having gas vesicles within their cells showed migration by changing buoyancy and according to Humphries \& Lyne ${ }^{24}$ a reason for the dominance of cyanophytes is due to this vertical migration which allows them to exploit any spatial separation between the nutrients in the hypolymnion and light intensity in the epilimnion. Unlike the Microcystis, P. cinctum showed active migration and as they are photoactive they normally swim up to the surface in the morning for photosynthesis. ${ }^{2 i}$

\section{Acknowledgement}

We are grateful to the Mahaweli Authority, Rajawella, for providing necessary facilities at the site and the Natural Resources, Energy \& Science Authority ( $R G / 93 / B / 1)$ for the financial support.

\section{References}

1. Ministry of Mahaweli Development (1986). Mahaueli projects \& programme 1987: a survey of the progress of work on the Accelerated Programme of Mahaweli Development in 1986 and the development proposed in 1987. Ministry of Lands and Land Development and the Ministry of Mahaweli Development of Sri Lanka, Colombo. pp. 55-63.

2. Piyasiri S. (1991). Limnology project at Mahaweli reservoirs. 1. Some physical properties of Kotmale, Victoria and Randenigala reservoirs. Vidyodaya Journal of Science 3(1): 54-61.

3. Piyasiri S. (1992). Limnology project at Mahaweli reservoirs: a limnological study at Kotmale, Victoria and Randenigala reservoirs. Vidyodaya Journal of Science 4(1): 155-166.

4. Piyasiri S. (1995), Eutrophication and blue green algal bloom problem of Kotmale reservoir in Sri Lanka. In: Tropical Limnology, Vol. 11 (Ed. K.H. Timotius \& F. Goltenboth) pp. 1-7. Satya Wacana University Press, Indonesia.

5. Chandrananda W.P.N. (1995). Limnology of the Kotmale reservoir and fish plankton interactions. Ph.D Thesis. University of Sri Jayewardenapura, Srj Lanka. pp. 5-54.

6. Central Engineering Consultancy Bureau, Sri Lanka (1994). Upper Kotmale Hydropower Project. EIA Report, Vol.1 (Main Report). Ceylon Electricity Board, Ministry of Power and Energy, Sri Lanka. pp. 3-19 -3-25. 
7. Abeywickrama B. A. (1979). The genera of the freshwater clgae of Sri Lanka, Part 1. UNESCO Man and the Biosphere national committee of Sri Lanka. Pub. No.6. pp. 5-44.

8. Abeywickrama B. A. \& Abeywickrama Lilani (1986). The genera of the freshwater algae of Sri Lanka, Part 11. UNESCO Man and the Biosphere national committee of Sri Lanka. Pub. No.15. pp. 6-45.

9. Whitford C.A. \& Schumacher G.J. (1973). A Manual of fieshocuter algae pp. 12-231. Sparks Press publishers, Raleigh, N.C.

10. Dokulil M., Bauer K. \& Silva I. (1983). An assessment of the phytoplankton biomass and primary productivity of Parakrama Samudra, a shallow man made lake in Sri Lanka. In: Limnology of Parakrama samudra, Sri Lanka : a case study of an ancient man made lake in the tropics. (Ed. F. Schiemer) pp 49-76 Dr. W. Junk Publisher, The Hague.

11. de Silva P.K. (1992). Physiochemical characteristics, phytoplankton and the fishery of Victoria reservoir. Ceylon Journal of Science (Biological. Science) 22(1): 29-39.

12. Hettiarachchi H.A.A \& Piyasiri S. (1994). Composition and population dynamics of plankton in Rantabe reservoir. Proc. Sri Lanka Ass. Aduml. Sci. 50(1). pp. 173.

13. Rott E. (1983). A contribution to the phytoplankton species composition of Parakrama samudra, an ancient man made lake in Sri Lanka. In: Limnology of Parakrama scumudra, Sri Lanka : a case study of an ancient man made lake in the tropics. (Ed. F. Schiemer) pp. 209-226. Dr. W. Junk Publishers. The Hague.

14. Schiemer Fritz (1995). Bottom up vs. top down control in tropical reservoir. management. In : Tropical limnology, Vol. 1 (Ed. K.H. Timotius \& F. Goltenboth) pp. 58-68. Satya Waeana University Press, Indonesia.

15. Moriarty Christine M \& Moriarty D.J.W. (1973). Quantitative estimation of the daily ingestion of phytoplankton by Tilapia nilotica and Haplochromis nigripinnis in Lake George, Uganda. Journal of Zoology, London. 171 pp $15-23$

16. Uku Jacqueline N. \& Mavuti Kenneth M. (1994). Comparative limnology, species diversity and biomass relations of zooplankton and phytoplankton in five freshwater lakes in Kenya. Hydrobiologia 272: 251-258. 
17. Horne A. J. \& Goldman C. R. (1994). Phytoplankton and periphyton . In : Limnology (2 nd edition) pp 226-264. McGraw - Hill Book Co., Singapore.

18. Johansson Dick (1988). Environmental impact of the Kotmale hydropower project in Sri Lanka. SWECO pp. 10-54.

19. Moss Brian (1980). Ecology of fiesh waters pp .38-85. Blackwell Scientific Publications, Oxford.

20. Parel Hans W. (1988). Nuisance phytoplankton blooms in coastal estuarine and inland waters. Limnology Oceanograph 33(4,0 part 2): 823847. The American Society of Limnology and Oceanography.

21. Ryding S.O. \& Rust W. (1989). Factors and processes affecting the degree of eutrophication. In: The Control of eutrophication of lakes and reservoirs. Man and Biosphere series. pp. 70-80.

22. Tundisi Jose G. (1983). A review of basic ecological processes interacting with production and standing-stock of phytoplankton in lakes and reservoirs in Brazil. Iydrobiologia 100:233-244. Dr. W. Junk publishers, the Hague, Netherlands.

23. Westlake D. F. et al. (1980). The functioning of the freshwater ecosystem, International biological programme. In : Primary production (Eds. E.D. Le Crene \& R.H. Lowec Mc Connell) 22 : 141-235, Cambridge University press, U.K.

24. Humphries S. E. \& Lyne V. (1988). Cyanophyte blooms; the role of cell busyancy. Limnology Oceanograph 31(1): 79-91.

25. Horne Alexander I. \& Goldman Charles R. (1994). Phytoplankton and periphyton In : Limnology (2nd edition). pp. 226-256. McGraw-Iill Inc, New York. 